Pol. J. Food Nutr. Sci., 2020, Vol. 70, No. 2, pp. 125-137

DOI: $10.31883 /$ pjfns/113533 http://journal.pan.olsztyn.pl

Original article

Section: Food Technology

\title{
Buckwheat as an Interesting Raw Material for Agricultural Distillate Production
}

\author{
Szymon Ługowoj, Maria Balcerek*, Katarzyna Pielech-Przybylska \\ Lodz University of Technology, Faculty of Biotechnology and Food Sciences, Institute of Fermentation \\ Technology and Microbiology, Wolczanska 171/173, 90-924 Lodz, Poland
}

Key words: buckwheat, reducing sugars, starch content, ethanol fermentation, agricultural distillate, volatile compounds

\begin{abstract}
The objective of this study was to assess the suitability of buckwheat grain for agricultural distillate production. The effects of the method of starch liberation on the physicochemical composition of the prepared mashes, fermentation results, the concentration of volatile compounds in the obtained distillates, and their organoleptic features, were investigated. The raw materials used were two cultivars of buckwheat grains, Panda and Kora. Both cultivars were characterized by similar starch content, however Panda cultivar had a significantly higher content of reducing sugars. Fermentation of the Kora cultivar-based mashes resulted in a higher fermentation efficiency (up to approximately 85\% of the theoretical yield) compared to the Panda cultivar-based mashes (up to approx. 75\%). Of the tested methods of starch liberation, the pressure-thermal treatment was revealed as superior, especially in the case of the Panda cultivar. In the case of the Kora cultivar, both the pressure-thermal method and the pressureless method of starch liberation resulted in a high process efficiency (up to $85 \%$ of the theoretical). Supplementation of the buckwheat mashes with $\left(\mathrm{NH}_{4}\right)_{2} \mathrm{HPO}_{4}$ improved fermentation results. The highest scores in sensory assessment were given to distillates from mashes prepared with the pressure-thermal treatment, which contained relatively low concentrations of undesirable compounds, such as acetaldehyde and methanol, and revealed pleasant organoleptic features.
\end{abstract}

\section{INTRODUCTION}

The alcohol industry is a rapidly developing sector of the economy in many countries. In order to ensure the highest quality of spirit, distilleries strive to reduce undesirable substances that may be found in agricultural distillates (raw spirits). The distilling industry is also investigating unconventional raw materials, with high ethanol efficiency yet interesting flavor and aroma properties for ethanol production. Today, distilleries use conventional cereals such as rye, wheat, and corn - namely raw materials with a high starch content, which translates into a high ethanol efficiency, i.e. above $40 \mathrm{~L}$ per $100 \mathrm{~kg}$. Potatoes are another widely used raw material, despite a much lower starch content in comparison to grains, at only $14.5 \%$ to $24.3 \%$, which allows producing only $10 \mathrm{~L}$ of ethanol per $100 \mathrm{~kg}$ [Banerjee \& Kundu, 2013].

Given its rapidly growing popularity all around the world, low soil requirements, and comparable starch content to widely used cereal grains, buckwheat could potentially be a new and valuable raw material for agricultural distillate production. In some countries, buckwheat is already used for the production of alcoholic beverages. For example, in France and the United States distillers use it in whisky production, while in Japan buckwheat grain is processed to make an alcoholic beverage called Soba Shōchū [Haros \& Sanz-Penella, 2017].

\footnotetext{
* Corresponding Author: E-mail: maria.balcerek@p.lodz.pl (Prof. M. Balcerek)
}

Buckwheat does not belong to the grass family (Poaceae), as cereals do, and differs also in its grain structure. It is therefore referred to as a pseudo-cereal. There are fifteen species of buckwheat, nine of which are used in agriculture, but only two are grown for food purposes - Fagopyrum esculentum and Fagopyrum tataricum [Bonafaccia et al., 2003; Dziadek et al., 2016]. Buckwheat has a similar chemical composition to plants usually considered as cereals. The overall composition of buckwheat grains depends on such conditions as the cultivars used, the kind of soil that the buckwheat grows on, and the kind of fertilizer used. The average starch content in buckwheat grain amounts to about $50 \% \mathrm{~d}$. m. The content of proteins is $12 \%$, lipids $4 \%$, soluble saccharides $2 \%$, dietary fiber 7\%, ash 2\%, and other substances 18\% [Im et al., 2003].

Buckwheat is often used in the manufacture of products intended for consumers suffering from celiac disease. It is used as a buckwheat malt in the production of gluten-free beer [Deželak et al., 2014]. In the case of distilled alcohols, the absence of gluten proteins in buckwheat grains is of little interest, because all spirits are gluten-free, regardless of whether gluten proteins are present in the raw material or not. The processes employed in the production of cereal-based distillates involve cereal processing, including extraction of starch from the cereals and its conversion to fermentable sugars, fermentation, and distillation of alcohol and other volatiles from the fermented mashes. The nature of the manufacturing process makes it unlikely that significant levels of allergenic proteins, peptides or fragments will be carried over into the distillate during a properly con- 
trolled distillation process [EFSA, 2004]. Interest in using buckwheat grains for the production of spirit drinks is due rather to the favorable starch content and aroma profile of its compounds, which open the possibility for efficient production of spirit with interesting, original sensory qualities, which could be used in the preparation of new spirit drinks (e.g. grain brandy, vodka, and others).

Sensory analysis is an integral part of the development process of products that fulfill consumer expectations. Aroma is of particular importance in satisfying consumer preferences. Sensory assessment is often complemented by determination of the concentration of volatile compounds in food and beverages, as this enables a better understanding of the effect of food components on the overall aroma intensity and/or perception of the final product [Starowicz et al., 2018]. Janes et al. [2009] identified the following aroma-active compounds responsible for the common organoleptic features of buckwheat: (E, E)- 2,4-decadienal, (E)-2-nonenal, 2,5-dimethyl-4-hydroxy-3(2H)-furanone, 2-methoxy4-vinylphenol, and 2-phenylacetaldehyde. According to Aoki \& Koizumi [1986], nonanal, octanal, and hexanal are also important aroma compounds in buckwheat. Various studies have investigated the key aroma compounds in buckwheat-based alcohol beverages. In the samples of the Japanese distilled beverage shochu, 22 potent odorants were identified, with ethyl cinnamate being the most intense aromaactive component [Sakaida et al., 2003]. A representative aroma compound in buckwheat-based alcoholic beverages, such as mead and beer, was found to be 2-phenylethanol [Wintersteen et al., 2005; Deželak et al., 2014]. A wide range of esters have also been identified, among which isoamyl acetate showed high aroma thresholds in buckwheat mead, shochu, and beer [Sakaida et al., 2003; Wintersteen et al., 2005; Deželak et al., 2014].

A high number of reports in the literature on the use of buckwheat for the production of various food products, including alcoholic beverages [Starowicz et al., 2018], and the direct interest of Polish producers of spirit drinks in the production of new, original beverages, prompted us to undertake research on the use of buckwheat grain for the production of agricultural distillate, which, after appropriate treatment (e.g. re-distillation with the separation of the head and tail fractions, or ageing in the presence of wood) could be used for the production of spirit drinks. The aim of the present study was therefore to investigate the suitability of buckwheat grain for agricultural distillate production, including the influence of the method of starch liberation on the physicochemical composition of the prepared mashes, fermentation results, the chemical composition of the obtained distillates, and their organoleptic features.

\section{MATERIALS AND METHODS}

\section{Raw materials}

Studies were conducted with using two cultivars of buckwheat (Fagopyrum esculentum Moench), Panda and Kora, classified as traditional cultivars of crop species grown in Poland [COBORU, 2019]. The raw material was purchased from the Plant Breeding Station (Palikije, Poland).

\section{Enzymatic preparations}

Liquefaction and saccharification of starch were carried out using the enzymatic preparations Termamyl SC ( $\alpha$-amylase from Bacillus stearothermophilus, EC 3.2.1.1) and SAN Extra (glucan 1,4- $\alpha$-glucosidase from Aspergillus niger, EC 3.2.1.3), purchased from Novozymes A/S (Bagsværd, Denmark). A supportive enzymatic preparation Viscoferm ${ }^{\circledR}$ (a multienzyme complex containing cellulase, EC 3.2.1.4; xylanase (endo-1,4-), EC 3.2.1.8; $\beta$-glucanase (endo-1,3(4)-), EC 3.2.1.6) (Novozymes A/S, Denmark) was used during the mashing process.

\section{Sweet mash production}

Prior to the alcoholic fermentation, sweet mashes were prepared from grains from the two buckwheat cultivars, using two methods of starch liberation commonly used in distilleries [Balcerek et al., 2016]: pressureless liberation of starch (PLS), and pressure-thermal treatment (steaming).

In the case of PLS, $5 \mathrm{~kg}$ of milled buckwheat grain was mixed with an adequate volume of water $(2.5 \mathrm{~L} / \mathrm{kg}$ of raw material) and the mixture was transferred into a stainless-steel tank with a water heating mantle. The mixture was heated to a temperature of $90^{\circ} \mathrm{C}$ with continuous stirring and Termamyl SC and Viscoferm preparations were added. The conditions for starch liquefaction were maintained for $1 \mathrm{~h}$. The mash was then cooled to approximately $65^{\circ} \mathrm{C}$ and digested with the saccharifying SAN Extra preparation. The sweet mash was finally cooled to fermentation temperature (approximately $30^{\circ} \mathrm{C}$ ).

For pressure-thermal treatment, $5 \mathrm{~kg}$ of whole buckwheat grain was placed in a tapered cylindrical steamer, filled previously with $17.5 \mathrm{~L}$ of water. Steaming was performed at $150^{\circ} \mathrm{C}$ and $0.4 \mathrm{MPa}$ for $30 \mathrm{~min}$, with periodical circulation of the content. After steaming, the content of the steamer was transferred into a steel-mashing vessel equipped with a heating/cooling coil and a thermometer. The steamed mass was cooled to a temperature of $90^{\circ} \mathrm{C}$ and mashed according to the same process as in the PLS method, but without Viscoferm preparation addition. Experiments were carried out on a semi-technical scale in the mini distillery of the Department of Spirit and Yeast Technology (Institute of Fermentation Technology and Microbiology, Lodz University of Technology, Poland). Figure 1 presents a scheme of the processes of buckwheat mashes preparation.

\section{Fermentation of buckwheat mashes}

Fermentation of buckwheat mashes was carried out in $10 \mathrm{~L}$ flat-bottomed flasks, each containing $6 \mathrm{~L}$ of mash with the $\mathrm{pH}$ adjusted to 4.8 (using $25 \% \mathrm{w} / \mathrm{v}_{2} \mathrm{SO}_{4}$ solution), supplemented or not with mineral nutrients for yeast (an aqueous solution of $\left(\mathrm{NH}_{4}\right)_{2} \mathrm{HPO}_{4}$ at a dose of $0.3 \mathrm{~g} / \mathrm{L}$ mash). Ethanol Red ${ }^{\circledR}$ dry distillery yeast (S. cerevisiae), dedicated for fermentation of mashes prepared from starchy raw materials (Fermentis, Division S.I. Lesaffre, France), was used. Prior to fermentation, the yeast slurry was prepared by suspending an appropriate amount of dry yeast in tap water $(0.5 \mathrm{~g} / \mathrm{L}$ sweet mash; yeast count $2.8 \times 10^{6} \mathrm{cfu} / \mathrm{mL}$ sweet mash) and disinfected by acidification using a sulfuric (VI) acid solution (the final $\mathrm{pH}$ of the yeast slurry was set at 2.5). The yeast slurry was kept at room temperature for $15 \mathrm{~min}$ to eliminate 
weaker yeast cells and undesirable bacterial cells. It was then added to the sweet mash samples. The inoculated mashes were carefully mixed prior to fermentation. The flasks were closed with stoppers equipped with fermentation pipes containing glycerol, and fermentation was performed at $35 \pm 2{ }^{\circ} \mathrm{C}$ for $72 \mathrm{~h}$. The fermentation process was controlled gravimetrically, by determining the decrease in the mass of the mashes related to the emission of $\mathrm{CO}_{2}$ (i.e., periodic measurement of the weight of the flat-bottomed flasks containing the fermenting mash).

\section{Distillation}

Once fermentation was complete, ethanol from the mashes was distilled using a unit consisting of a distillation flask, a Liebig cooler, a flask for collecting ethanol, and a thermometer. Distillates containing 20-25\% vol. ethanol were strengthened to ethanol contents of approximately $42-43 \%$ vol. in a glass distillation apparatus with a special dephlegmator/condenser, according to the method provided in a work by Young [1922].
A

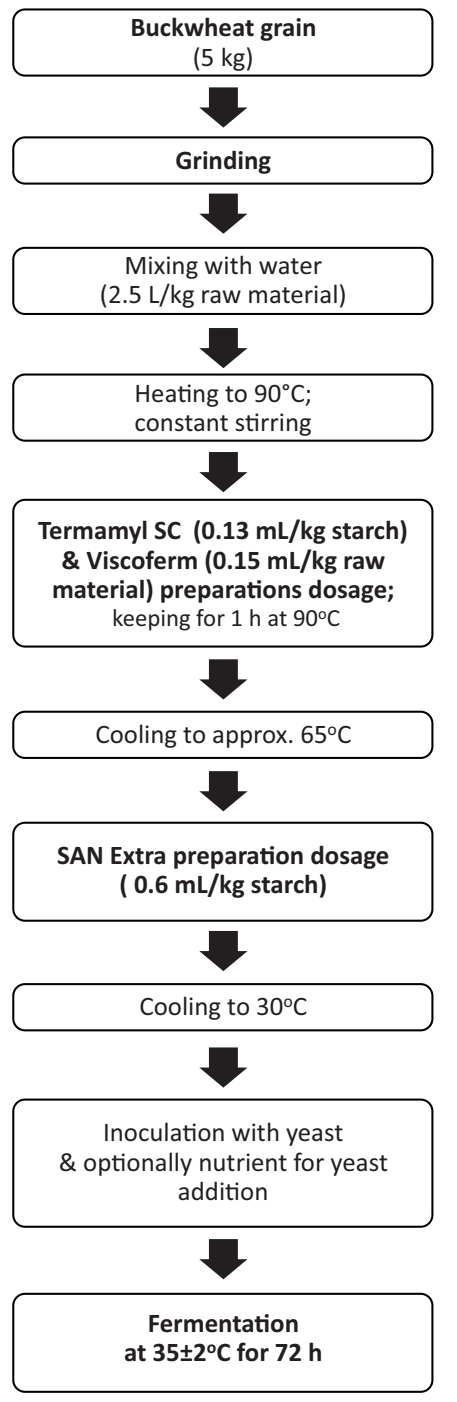

B
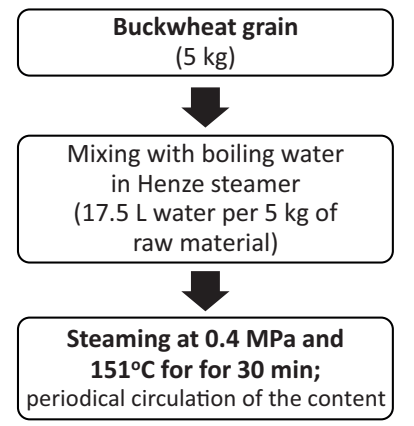

Cooling to $90^{\circ} \mathrm{C}$

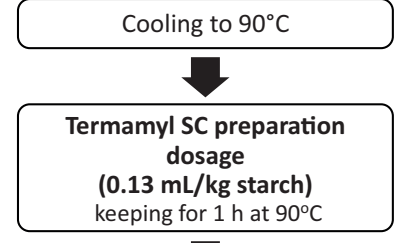

keeping for $1 \mathrm{~h}$ at $90^{\circ} \mathrm{C}$

Cooling to approx. $65^{\circ} \mathrm{C}$

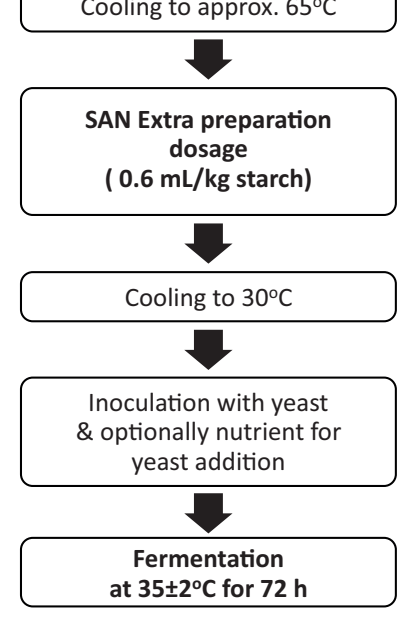

at $35 \pm 2^{\circ} \mathrm{C}$ for 72

FIGURE 1. Scheme of buckwheat mash preparation: A - pressureless liberation of starch (PLS) method; B - pressure-thermal starch liberation method.

\section{Analytical methods}

\section{Buckwheat grains}

The raw material was analyzed for contents of: starch using the Ewers method [PN-EN ISO 10520, 2002], reducing and total sugars (after acid hydrolysis) using DNS reagent [Miller, 1959], moisture with the use of a WPS-305 Radwag weighing dryer $\left(105^{\circ} \mathrm{C}\right)$, and total nitrogen according to the Kjeldahl method, calculated as protein $(\mathrm{N} \times 5.7)$ and $\mathrm{ex}-$ pressed as the percentage of dry weight [AOAC, 1995].

\section{Sweet and fermented mashes}

Both the sweet and fermented mashes were analyzed for: $\mathrm{pH}$; extract - the concentration of dissolved solids, mostly sugar (in the sweet mashes, total extract; in the fermented mashes, apparent extract in the presence of alcohol, and real extract after distillation of alcohol), using an aerometer with a scale in $\mathrm{g} / \mathrm{L}$ [Balcerek et al., 2016]; the concentration of reducing sugars and total sugars [Miller, 1959]; dextrin concentration calculated as the difference between total sugars and reducing sugars, using a conversion coefficient of 0.9 ; and ethanol content using an areometer with a scale in percentage of ethanol by volume, after distillation from fermented mashes in a Super Dee digital distilling unit (Gibertini, Novate Milanese, Italy).

\section{Distillates}

Chromatographic analysis of the volatile compounds in the obtained distillates was carried out using gas chromatography (GC apparatus) (Agilent 7890A, Agilent Technologies, Santa Clara, CA, USA) with a mass spectrometer (Agilent MSD 5975C, USA). An Agilent VF-WAX MS polar capillary column $(60 \mathrm{~m} \times 0.50 \mu \mathrm{m} \times 0.32 \mathrm{~mm})$ was used to separate the compounds. The GC oven temperature was programmed to increase from $40(6 \mathrm{~min})$ to $80^{\circ} \mathrm{C}$ at a rate of $2^{\circ} \mathrm{C} / \mathrm{min}$, and then to $220^{\circ} \mathrm{C}$ at a rate of $10^{\circ} \mathrm{C} / \mathrm{min}$ (hold time $5 \mathrm{~min}$ ). The flow rate of the carrier gas (helium) through the column was $1.2 \mathrm{~mL} / \mathrm{min}$. The temperature of the injector (split/splitless) was $250^{\circ} \mathrm{C}$. Direct injections of the tested distillates $(1 \mu \mathrm{L})$ were made in the split mode $(1: 40)$. The conditions for MS were as follows: ion source temperature $230^{\circ} \mathrm{C}$; transfer line temperature $250^{\circ} \mathrm{C}$; quadrupole temperature $150^{\circ} \mathrm{C}$; ionization energy $70 \mathrm{eV}$. Identification of the volatile components was based on a comparison of their mass spectra with the mass spectra in the NIST/EPA/NIH Mass Spectra Library (2012; Version 2.0g.). Retention indices (RIs) were also compared with reference compounds and literature data [Chida et al., 2004]. The RIs were calculated relative to a homologous series of $n$-alkanes from pentane to octadecane. Quantification of the volatile compounds was performed using calibration curves in the selected ion monitoring mode (SIM). Six calibration solutions, containing different concentrations of each standard compound, were prepared with 4-heptanone, which was added to a concentration of $45 \mathrm{mg} / \mathrm{L}$ of absolute alcohol of the analyzed samples as an internal standard, to monitor instrument response and retention time stability. Quantitative analysis was conducted using Agilent MassHunter software (Agilent Technologies, Santa Clara, CA, USA). The concentrations of the determined volatile compounds were expressed in $\mathrm{mg} / \mathrm{L}$ alcohol $100 \%$ vol.. 


\section{Sensory analysis}

Samples of the buckwheat distillates were subjected to sensory evaluation by a panel of six qualified assessors, who possess knowledge of spirits and their quality requirements. Sensory assessment was performed using the Buxbaum model of positive ranking [Tešević et al., 2005]. This model is based on four sensory experiences, rated with a maximum of 20 points overall. Each judge gives a score for color, 0-2; clearness, 0-2; aroma (odor), 0-4; and taste, 0-12.

\section{Calculations}

Fermentation efficiency and total sugar intake were calculated to evaluate the fermentation process. The intake of sugars was calculated as the ratio of sugars utilized during fermentation to their initial content in the mash and expressed as a percentage. Fermentation efficiency was calculated according to the stoichiometric Gay-Lussac equation in relation to total sugars and expressed as a percentage of the theoretical yield [Nicol \& Rum, 2003].

\section{Statistical analysis}

All fermentation variants were prepared and analyzed in triplicate. The results were tested statistically by analysis of variance with a significance level $\mathrm{p} \leq 0.05$ using Origin 7.5 software (OriginLab Corporation, Northampton, MA, USA).

\section{RESULTS AND DISCUSSION}

\section{Chemical composition of raw material}

Based on the analysis of the raw material (Table 1), the moisture levels of both buckwheat cultivars were found to

TABLE 1. Chemical composition of buckwheat cultivars used in the study.

\begin{tabular}{lcc}
\hline Components & Kora cv. & Panda cv. \\
\hline $\begin{array}{l}\text { Moisture } \\
\text { (g/kg) }\end{array}$ & $120.9 \pm 8.7^{\mathrm{a}}$ & $121.9 \pm 8.0^{\mathrm{a}}$ \\
$\begin{array}{l}\text { Protein (Nx6.25) } \\
\text { (g/kg d.m.) }\end{array}$ & $107.5 \pm 0.8^{\mathrm{a}}$ & $98.5 \pm 0.2^{\mathrm{b}}$ \\
$\begin{array}{l}\text { Reducing sugars } \\
\text { (g glucose/kg) }\end{array}$ & $29.1 \pm 0.4^{\mathrm{b}}$ & $133.6 \pm 8.1^{\mathrm{a}}$ \\
$\begin{array}{l}\text { Starch } \\
(\mathrm{g} / \mathrm{kg})\end{array}$ & $493.5 \pm 51.7^{\mathrm{a}}$ & $452.3 \pm 51.9^{\mathrm{a}}$ \\
\hline
\end{tabular}

Results expressed as mean values $\pm S E(n=3)$; values with different superscript letters in the same row are significantly different $(p<0.05)$. be similar $(\mathrm{p}>0.05)$. The protein content in the raw materials was between $98.5 \pm 0.2 \mathrm{~g} / \mathrm{kg}$ (Panda) and $107.5 \pm 0.8 \mathrm{~g} / \mathrm{kg}$ (Kora). The greatest differences between the buckwheat cultivars were in terms of reducing sugars content which was significantly higher in the Panda cultivar (133.6 $\pm 8.1 \mathrm{~g}$ glucose $/ \mathrm{kg}$ ), compared to the second cultivar $(29.1 \pm 0.4 \mathrm{~g}$ glucose $/ \mathrm{kg})$. Despite the lower content of reducing sugars, the Kora cultivar had a similar $(\mathrm{p}>0.05)$ starch content $(493.5 \pm 51.7 \mathrm{~g} / \mathrm{kg}$, i.e. $561.3 \pm 58.9 \mathrm{~g} / \mathrm{kg} \mathrm{d} . \mathrm{m})$ to the Panda cultivar $(452.3 \pm 51.9 \mathrm{~g} / \mathrm{kg}$, i.e. $515.0 \pm 59.2 \mathrm{~g} / \mathrm{kg} \mathrm{d.m}$.). If these results are compared with the available literature [Stempińska \& Soral-Smietana, 2006], it can be concluded that both cultivars used in our study had a lower starch content (Panda, $642.3 \mathrm{~g} / \mathrm{kg}$ d.m., Kora, $635.4 \mathrm{~g} / \mathrm{kg}$ d.m.), but similar values of the other analyzed parameters. Using appropriate agrotechnical measures, it is possible to significantly affect the yield and quality of cereal grains. Stankiewicz [2004] showed that the total protein content in triticale grain increased with sowing density, while the starch content decreased only at the highest sowing density (750 grains per $\left.\mathrm{m}^{2}\right)$. The recommended dose of selective herbicides also caused an increase in the total protein content and a reduction in starch level in the grain.

\section{Physicochemical composition of sweet mashes}

After preparation of all the variants of sweet mashes, their physicochemical analysis was conducted (Table 2), including measurement of $\mathrm{pH}$ and determination the concentration of soluble solids (expressed as total extract), reducing sugars, and dextrin.

The $\mathrm{pH}$ of sweet mashes prepared from both buckwheat cultivars with the use of pressure-thermal treatment ranged from $5.7 \pm 0.1$ to $5.9 \pm 0.1$ and was lower $(\mathrm{p}<0.05)$ than in analogous samples prepared using the pressure starch liberation method (between $6.2 \pm 0.1$ and 6.4 \pm 0.1 ). Before inoculation with yeast slurry, the $\mathrm{pH}$ value of all the mashes was adjusted to 4.8 .

The total extract content in the sweet mashes differed depending on the buckwheat cultivars used. There were no significant differences $(p>0.05)$ in the value of this parameter compared to the starch liberation method. The total extract of mashes prepared from Kora cultivar was similar $(130.1 \pm 0.3 \mathrm{~g} / \mathrm{L})$ after the use of both the pressure-thermal method and the PLS method. Mashes prepared from the second buckwheat cultivar (Panda) had a higher $(\mathrm{p}<0.05)$ soluble solids content than those made of the Kora cultivar. Most likely, this difference was due to the higher total

TABLE 2. Chemical composition of sweet buckwheat mashes.

\begin{tabular}{l|c|c|c|c}
\hline \multirow{2}{*}{ Parameter } & \multicolumn{2}{|c|}{ Kora cv. } & \multicolumn{2}{c}{ Panda cv. } \\
\cline { 2 - 5 } & $\begin{array}{c}\text { Pressure-thermal } \\
\text { treatment }\end{array}$ & $\begin{array}{c}\text { Pressureless starch } \\
\text { liberation }\end{array}$ & $\begin{array}{c}\text { Pressure-thermal } \\
\text { treatment }\end{array}$ & $\begin{array}{c}\text { Pressureless starch } \\
\text { liberation }\end{array}$ \\
\hline $\mathrm{pH}$ & $5.9 \pm 0.1^{\mathrm{b}}$ & $6.2 \pm 0.1^{\mathrm{a}}$ & $5.7 \pm 0.1^{\mathrm{b}}$ & $6.4 \pm 0.1^{\mathrm{a}}$ \\
Extract (g/L) & $129.8 \pm 0.3^{\mathrm{c}}$ & $133.1 \pm 0.3^{\mathrm{b}}$ & $140.9 \pm 0.5^{\mathrm{a}}$ & $140.8 \pm 0.6^{\mathrm{a}}$ \\
Reducing sugars (g glucose/L) & $36.3 \pm 0.5^{\mathrm{c}}$ & $58.1 \pm 1.2^{\mathrm{b}}$ & $36.5 \pm 0.8^{\mathrm{c}}$ & $65.8 \pm 1.5^{\mathrm{a}}$ \\
Dextrin (g/L) & $61.4 \pm 2.1^{\mathrm{b}}$ & $37.8 \pm 1.7^{\mathrm{d}}$ & $76.8 \pm 0.6^{\mathrm{a}}$ & $45.6 \pm 1.7^{\mathrm{c}}$ \\
\hline
\end{tabular}

Results expressed as mean values $\pm \mathrm{SE}(\mathrm{n}=3)$; values with different superscript letters in the same row are significantly different $(\mathrm{p}<0.05)$. 
sugars content (the sum of reducing sugars and hydrolyzed starch) in the Panda cultivar. However, taking into consideration the starch liberation method, the total extract of Panda cultivar-based mashes did not show significant differences and was similar $(140.9 \pm 0.5 \mathrm{~g} / \mathrm{L})(\mathrm{p}>0.05)$ for the samples prepared with both methods.

The initial content of reducing sugars in the sweet mashes from both buckwheat cultivars was higher in the mashes prepared with the PLS method. For the Panda cultivar, it was $65.8 \pm 1.5 \mathrm{~g}$ glucose/L mash, whereas the mashes prepared from the Kora cultivar had a lower reducing sugars content, i.e. $58.1 \pm 1.2 \mathrm{~g}$ glucose/L mash. In turn, the concentrations of reducing sugars in the mashes prepared using the pressure-thermal method were significantly $(\mathrm{p}<0.05)$ lower than in the samples prepared with the PLS method, but similar for both cultivars $(36.3 \pm 0.5 \mathrm{~g}$ glucose $/ \mathrm{L}$ mash). In terms of dextrin content, the samples prepared with the steaming method contained from $61.4 \pm 2.1 \mathrm{~g} / \mathrm{L}$ mash (Kora cultivar) to $76.8 \pm 0.6 \mathrm{~g} / \mathrm{L}$ mash (Panda cultivar). The PLS method led to a significantly lower $(\mathrm{p}<0.05)$ dextrin content in the mashes before fermentation, i.e. $37.8 \pm 1.7 \mathrm{~g} / \mathrm{L}$ mash (Kora cultivar) and $45.6 \pm 1.7 \mathrm{~g} / \mathrm{L}$ mash (Panda cultivar). The relatively low starch saccharification level may due to the simultaneous saccharification and fermentation, without a dedicated starch hydrolysis stage. However, this technology is commonly used in industry, because it has a positive influence on yeast fermentation activity, by eliminating osmotic stress caused by a high sugar content in mashes [Russell, 2003].

\section{Physicochemical composition of fermented mashes}

Physicochemical analysis of the fermented mashes was carried out in order to determine whether the course of the process and its efficiency were correct (Table 3). During any fermentation, yeast secretes $\mathrm{H}^{+}$ions, causing a decline in the $\mathrm{pH}$ value of the medium. The $\mathrm{pH}$ value of most of the fermented mashes ranged between $4.30 \pm 0.01$ and $4.55 \pm 0.01$, which is consistent with literature data and confirms the correct duration of the fermentation process [Russell, 2003]. Mashes prepared from the Kora cultivar using the PLS method showed lower $\mathrm{pH}$, from $3.94 \pm 0.01$ to $4.08 \pm 0.01$. Often, sharp decreases in $\mathrm{pH}$ are due fermentation medium con- tamination by lactic acid bacteria (LAB). This is undesirable for the course of fermentation and results in a reduced spirit yield, since the sugars consumed by the bacteria are no longer available to the yeast for ethanol production [Balcerek et al., 2016; Russell, 2003]. Moreover, one of the Kora cultivarbased mashes was not supplemented with nutrient for yeast. Gravimetric monitoring of the course of fermentation indicated a lower decrease in the mass of this sample, resulting from lower $\mathrm{CO}_{2}$ liberation, which, in turn, is connected with slower fermentation compared to mash with $\left(\mathrm{NH}_{4}\right)_{2} \mathrm{HPO}_{4}$ (data not shown).

The factor used in the distilling industry to assess the apt course of the fermentation process is the apparent extract content, measured in the presence of ethanol. In the case of well-fermented distillery mashes with an initial extract content of approximately $180 \mathrm{~g} / \mathrm{L}$, the apparent extract content should not exceed 10-15 g/L [Kotarska et al., 2006]. The apparent extract content in all fermented mashes varied widely between $3.00 \pm 0.01 \mathrm{~g} / \mathrm{L}$ in the case of Kora cultivarbased mashes (prepared by steaming and supplemented with mineral nutrient for yeast) and $12.00 \pm 0.01 \mathrm{~g} / \mathrm{L}$ for mashes prepared from Panda cultivar with the PLS method, without supplementation with minerals. The mashes prepared from Panda cultivar with the PLS method and supplemented with $\left(\mathrm{NH}_{4}\right)_{2} \mathrm{HPO}_{4}$ also showed the highest real extract content $(43.14 \pm 0.01 \mathrm{~g} / \mathrm{L})$, while the lowest value of this parameter $(27.52 \pm 0.01 \mathrm{~g} / \mathrm{L})$ was observed in the samples prepared with the pressure-thermal method and supplemented with $\left(\mathrm{NH}_{4}\right)_{2} \mathrm{HPO}_{4}$ (where the Kora cultivar was used).

The alcohol content in the samples prepared from Kora buckwheat cultivar ranged from $4.99 \pm 0.15 \%$ vol. to $5.89 \pm 0.35 \%$ vol. In terms of alcohol biosynthesis, the preferred method of buckwheat starch liberation was found to be the pressure-thermal treatment. Moreover, fermentation medium supplementation with mineral nutrients for yeast was found advisable, irrespective of the method of mash preparation. The lowest ethanol content was found in the sample of mash prepared with the PLS method and fermented without additional mineral nutrient for yeast. This sample simultaneously showed the lowest $\mathrm{pH}(3.94 \pm 0.01)$ after fermentation. Muthaiyan et al. [2011] demonstrated that the successive

TABLE 3. Chemical composition of fermented buckwheat mashes.

\begin{tabular}{|c|c|c|c|c|c|c|c|c|}
\hline \multirow{3}{*}{ Parameter } & \multicolumn{4}{|c|}{ Kora cv. } & \multicolumn{4}{|c|}{ Panda cv. } \\
\hline & \multicolumn{2}{|c|}{ Pressure-thermal treatment } & \multicolumn{2}{|c|}{ Pressureless starch liberation } & \multicolumn{2}{|c|}{ Pressure-thermal treatment } & \multicolumn{2}{|c|}{ Pressureless starch liberation } \\
\hline & $\begin{array}{c}\text { with } \\
\left(\mathrm{NH}_{4}\right)_{2} \mathrm{HPO}_{4}\end{array}$ & $\begin{array}{c}\text { without } \\
\left(\mathrm{NH}_{4}\right)_{2} \mathrm{HPO}_{4} \\
\end{array}$ & \begin{tabular}{c|c|} 
with \\
$\left(\mathrm{NH}_{4}\right)_{2} \mathrm{HPO}_{4}$ \\
\end{tabular} & $\begin{array}{c}\text { without } \\
\left(\mathrm{NH}_{4}\right)_{2} \mathrm{HPO}_{4}\end{array}$ & $\begin{array}{c}\text { with } \\
\left(\mathrm{NH}_{4}\right)_{2} \mathrm{HPO}_{4}\end{array}$ & $\begin{array}{c}\text { without } \\
\left(\mathrm{NH}_{4}\right)_{2} \mathrm{HPO}_{4} \\
\end{array}$ & $\begin{array}{c}\text { with } \\
\left(\mathrm{NH}_{4}\right)_{2} \mathrm{HPO}_{4} \\
\end{array}$ & \begin{tabular}{|c} 
without \\
$\left(\mathrm{NH}_{4}\right)_{2} \mathrm{HPO}_{4}$ \\
\end{tabular} \\
\hline $\mathrm{pH}$ & $4.41 \pm 0.01^{\mathrm{c}}$ & $4.34 \pm 0.01^{\mathrm{d}}$ & $4.08 \pm 0.01^{\mathrm{f}}$ & $3.94 \pm 0.01^{\mathrm{g}}$ & $4.52 \pm 0.01^{\mathrm{b}}$ & $4.55 \pm 0.01^{\mathrm{a}}$ & $4.30 \pm 0.01^{\mathrm{e}}$ & $4.39 \pm 0.01^{\mathrm{c}}$ \\
\hline Apparent extract (g/L) & $5.00 \pm 0.01^{\mathrm{f}}$ & $3.00 \pm 0.01^{\mathrm{g}}$ & $10.40 \pm 0.01^{\mathrm{b}}$ & $10.40 \pm 0.01^{\mathrm{b}}$ & $9.20 \pm 0.01^{\mathrm{c}}$ & $5.50 \pm 0.01^{\mathrm{e}}$ & $8.80 \pm 0.01^{\mathrm{d}}$ & $12.00 \pm 0.01^{\mathrm{a}}$ \\
\hline Real extract $(\mathrm{g} / \mathrm{L})$ & $27.52 \pm 0.01^{\mathrm{g}}$ & $29.13 \pm 0.01^{\mathrm{f}}$ & $40.50 \pm 0.01^{\mathrm{b}}$ & $35.52 \pm 0.01^{\mathrm{c}}$ & $33.52 \pm 0.01^{\mathrm{d}}$ & $33.54 \pm 0.01^{\mathrm{d}}$ & $29.51 \pm 0.01^{\mathrm{e}}$ & $43.14 \pm 0.01^{\mathrm{a}}$ \\
\hline Alcohol (\% vol.) & $5.89 \pm 0.35^{\mathrm{ab}}$ & $5.27 \pm 0.21^{\mathrm{cd}}$ & $5.50 \pm 0.21^{\mathrm{bc}}$ & $4.99 \pm 0.15^{\mathrm{de}}$ & $5.96 \pm 0.18^{\mathrm{a}}$ & $4.47 \pm 0.13^{\mathrm{f}}$ & $4.86 \pm 0.11^{\mathrm{e}}$ & $3.80 \pm 0.21^{\mathrm{g}}$ \\
\hline $\begin{array}{l}\text { Reducing sugars } \\
\text { (g glucose/L) }\end{array}$ & $0.52 \pm 0.03^{\mathrm{g}}$ & $0.82 \pm 0.01^{\mathrm{f}}$ & $1.52 \pm 0.20^{\mathrm{e}}$ & $1.23 \pm 0.12^{\mathrm{e}}$ & $1.81 \pm 0.06^{\mathrm{d}}$ & $2.12 \pm 0.14^{c}$ & $2.83 \pm 0.15^{\mathrm{b}}$ & $3.43 \pm 0.14^{\mathrm{a}}$ \\
\hline Dextrin $(\mathrm{g} / \mathrm{L})$ & $3.81 \pm 0.22^{\mathrm{e}}$ & $4.23 \pm 0.25^{\mathrm{e}}$ & $6.33 \pm 0.11^{\mathrm{c}}$ & $5.92 \pm 0.13^{\mathrm{d}}$ & $3.83 \pm 0.41^{\mathrm{ef}}$ & $3.22 \pm 0.24^{\mathrm{f}}$ & $7.34 \pm 0.22^{\mathrm{b}}$ & $7.72 \pm 0.13^{\mathrm{a}}$ \\
\hline
\end{tabular}

Results expressed as mean values $\pm \mathrm{SE}(\mathrm{n}=3)$; values with different superscript letters in the same row are significantly different $(\mathrm{p}<0.05)$. 
production of acids during fermentation shortens the lifespan of yeast by up to $60 \%$, while the synergistic action of acetic and lactic acids decreases the yeast growth rate, the glucose consumption rate, and ethanol yield. Alcohol contents varied widely in the fermented mashes from Panda cultivar. However, the relationship between the alcohol content, the method of starch liberation, and supplementation with minerals was analogous to that observed in the case of Kora cultivar-based

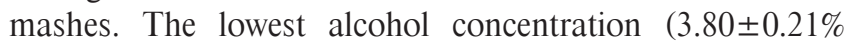
vol.) was determined in the sample prepared using the PLS method, without supplementation with mineral nutrients, whereas the highest one $(5.96 \pm 0.18 \%$ vol.) was determined in the mash from steamed raw material and supplemented with $\left.\left(\mathrm{NH}_{4}\right)_{2} \mathrm{HPO}_{4}\right)(\mathrm{p}<0.05)$. The lower ethanol concentration may due to the microbiological infection in the medium prepared with the PLS method. At the temperature of $90^{\circ} \mathrm{C}$ usually applied in this process most viable vegetative forms of microorganisms are inactivated, except for spores which are heat resistant. Moreover, secondary microbial contamination is possible in subsequent stages of processing, due to the presence of microorganisms in the water, air, yeast, and distillery equipment [Narendranath et al., 2003]. In this study, the absence of added nutrients for yeast may have been the reason for the weak condition of the yeast in some mashes, which may have resulted in incomplete fermentation [Pielech-Przybylska et al., 2017].

Reducing sugars content differed the least in the mashes prepared with the same method of starch liberation. For mashes from Kora cultivar prepared by steaming the raw material, it ranged from $0.52 \pm 0.03$ to $0.82 \pm 0.01 \mathrm{~g}$ glucose/L mash. Meanwhile, in those prepared with the use of the PLS method, it was from $1.23 \pm 0.12$ to $1.52 \pm 0.20 \mathrm{~g}$ glucose/L mash. The mashes from Panda cultivar contained on average higher amounts of reducing sugars $(\mathrm{p}<0.05)$; in the steamed samples, the reducing sugars content was be- tween $1.81 \pm 0.06$ and $2.12 \pm 0.14 \mathrm{~g}$ glucose/L mash, whereas in mashes prepared with the PLS method it ranged from $2.83 \pm 0.15$ to $3.43 \pm 0.14$ g glucose $/ \mathrm{L}$ mash.

Relatively higher concentrations of non-hydrolyzed dextrin (between $5.92 \pm 0.13$ and $7.72 \pm 0.13 \mathrm{~g} / \mathrm{L}$ mash) were found to remain in the buckwheat mashes prepared with the PLS method than in samples in which the buckwheat grains were subjected to pressure-thermal treatment in a Henze steamer. Under a water vapor pressure of $0.4 \mathrm{MPa}\left(150^{\circ} \mathrm{C}\right)$, the cellular structure of cereal grain is destroyed, enabling the release and accessibility of starch to enzymes. Moreover, gelatinization of starch, which takes place in the pressure-thermal method, facilitates the hydrolysis of this polysaccharide by amylolytic enzymes [Balcerek et al., 2016].

\section{Fermentation factors}

Sugar intake by the yeast during fermentation was calculated on the basis of the sugar content in the sweet and fermented mashes. The percentage value of sugar consumption is shown in Figure 2. In the mashes prepared from both the Kora and Panda cultivars, the highest sugar consumption (from $95.03 \pm 1.90 \%$ to $95.32 \pm 1.91 \%)(p<0.05)$ was determined in the samples prepared by the pressure-thermal treatment. The addition of $\left(\mathrm{NH}_{4}\right)_{2} \mathrm{HPO}_{4}$ was not observed to have an effect on the sugar intake. On the contrary, lower sugar consumption (between $90.13 \pm 1.83 \%$ and $92.31 \pm 1.85 \%$ ) ( $p>0.05$ ) was observed in the mashes prepared with the PLS method. Supplementation with minerals was also found to have no effect. Sugar intake during fermentation of the buckwheat mashes was comparable with that for fermented mashes prepared from conventional raw materials (cereals) used in ethanol production [Balcerek et al., 2016; Pielech-Przybylska et al., 2017].

The efficiency of ethanol biosynthesis (expressed as a percentage of the theoretical amount) was also calculated to

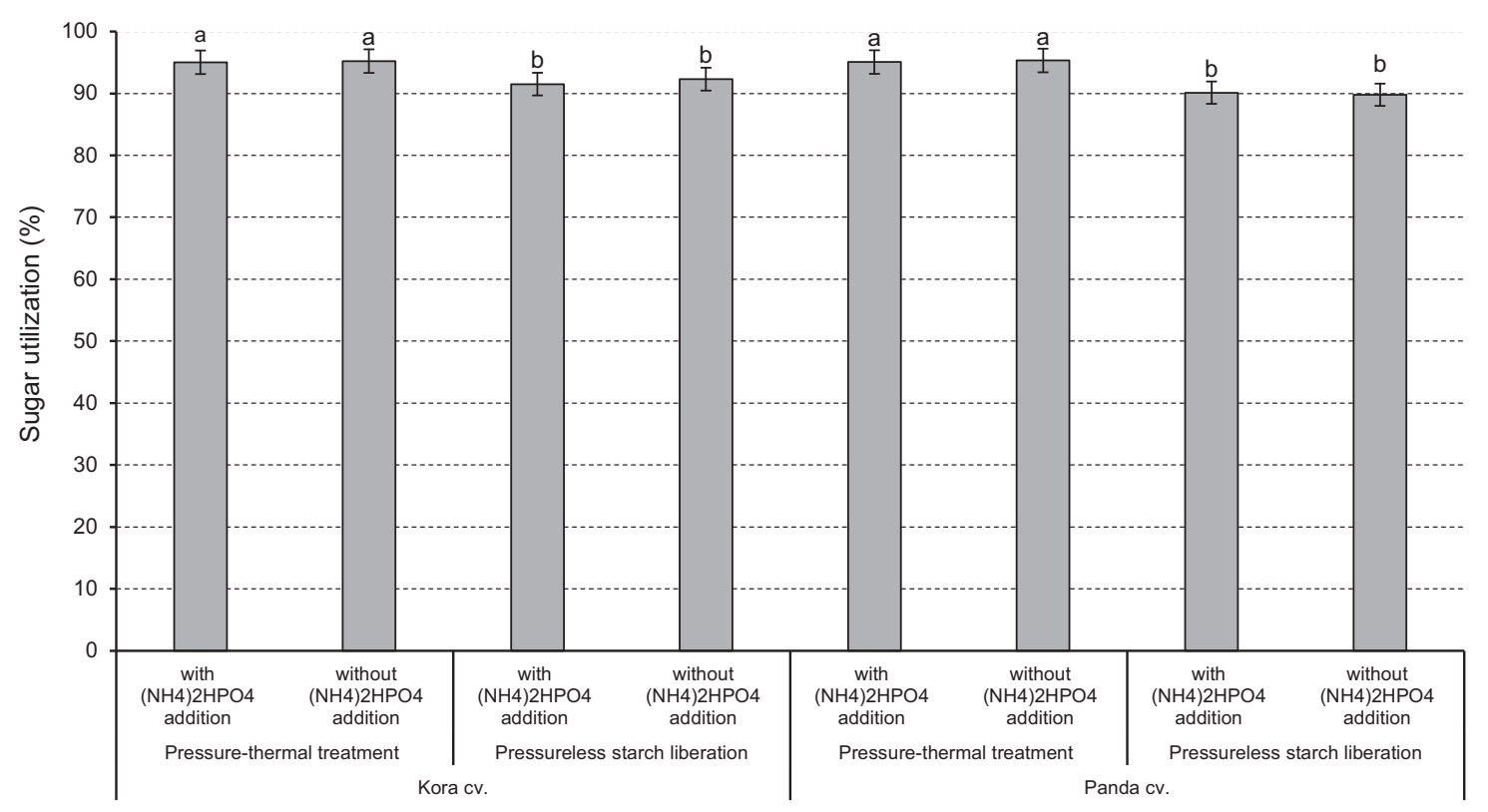

FIGURE 2. Sugar consumption in distillery mashes prepared from buckwheat grain. Different letters indicate significant differences ( $<<0.05)$ between mean values. 
evaluate the fermentation results (Figure 3). For the mashes prepared from Kora cultivar, the highest value of this parameter, at $84.88 \pm 2.5 \%$ of theoretical efficiency, was registered for the fermentation variant based on the PLS method and supplemented with mineral nutrient for yeast. Fermentation of mashes with initial pressure-thermal treatment (both with and without the addition of $\left.\left(\mathrm{NH}_{4}\right)_{2} \mathrm{HPO}_{4}\right)$ resulted in similar fermentation efficiencies (from $81.68 \pm 2.45 \%$ to $82.84 \pm 2.34 \%)(p>0.05)$. The lowest efficiency of ethanol biosynthesis $(77.01 \pm 2.31 \%$ of the theoretical yield) was obtained for mashes prepared with the PLS method, without supplementation with minerals. These results suggest that deficiency of $\left(\mathrm{NH}_{4}\right)_{2} \mathrm{HPO}_{4}$ was responsible for lower ethanol production.

After fermentation of the mashes prepared from Panda buckwheat cultivar, fermentation efficiency was significantly lower than in the mashes prepared from Kora cultivar. Large differences in the fermentation efficiency were also observed between individual variants (Figure 3 ). The mashes prepared by steaming and supplemented with $\left(\mathrm{NH}_{4}\right)_{2} \mathrm{HPO}_{4}$ were characterized by the highest fermentation efficiency $(75.54 \pm 2.27 \%$ of the theoretical). The rest of the prepared samples of mashes were characterized by considerably $(p<0.05)$ lower fermentation efficiency, which ranged between $50.40 \pm 1.51 \%$ and $64.46 \pm 1.93 \%$ of the theoretical yield. Taking into consideration the chemical composition of the mashes in which the low ethanol yield was obtained, there are no simple reasons to explain these results. The $\mathrm{pH}$ values of the mashes were similar to those observed in the samples with high fermentation efficiency, which eliminates the possibility of a high level of microbial contamination. It is possible that the relatively high initial content of reducing sugars in the mashes, and the lack of nutrients for yeast in selected samples, could cause osmotic stress, and as a consequence lower fermentation efficiency.
When the results of this study are compared with literature data [Balcerek et al., 2016; Pielech-Przybylska et al., 2017], it can be stated that the mashes prepared from Kora cultivar showed similar fermentation efficiency to mashes prepared from conventional raw materials, such as rye or wheat. The exceptions were samples made of the Panda cultivar, which were characterized by much lower fermentation efficiency compared to both the Kora cultivar and mashes made of other popular raw materials (rye, barley).

\section{Characteristics of the obtained distillates}

During the fermentation process, yeast produces ethanol and $\mathrm{CO}_{2}$. Simultaneously, the synthesis of many volatile compounds occurs, such as carbonyl compounds, alcohols, esters, and organic acids, which determine the flavor and aroma of alcoholic beverages [Stewart, 2017]. Evaluation of the chemical composition of the obtained distillates revealed that the buckwheat cultivar, the method of sweet mash preparation, and the supplementation of the fermentation medium with nutrients for yeast, all had an effect (Table 4).

Carbonyl compounds, represented by aldehydes and ketones, are intermediates in the decarboxylation of alpha-keto acids to alcohols as well as in the synthesis and oxidation of alcohols. Their concentrations in agricultural distillates depend on the quality of the raw material, its chemical composition, the conditions of the technological process, and microbial contamination. Aldehydes are often observed to have a negative influence on the quality characteristics of spirits [Plutowska et al., 2010]. In the spirits obtained from buckwheat mashes, the highest concentration of acetaldehyde $(606.73 \pm 20.67 \mathrm{mg} / \mathrm{L}$ alcohol $100 \%$ vol.) was determined in the distillate obtained from the Kora cultivar with the use of steaming for starch liberation and without supplementation with minerals $(\mathrm{p}<0.05)$. The lowest content of this compound $(208.71 \pm 9.71 \mathrm{mg} / \mathrm{L}$ alcohol $100 \%$ vol.) occurred in the distil-

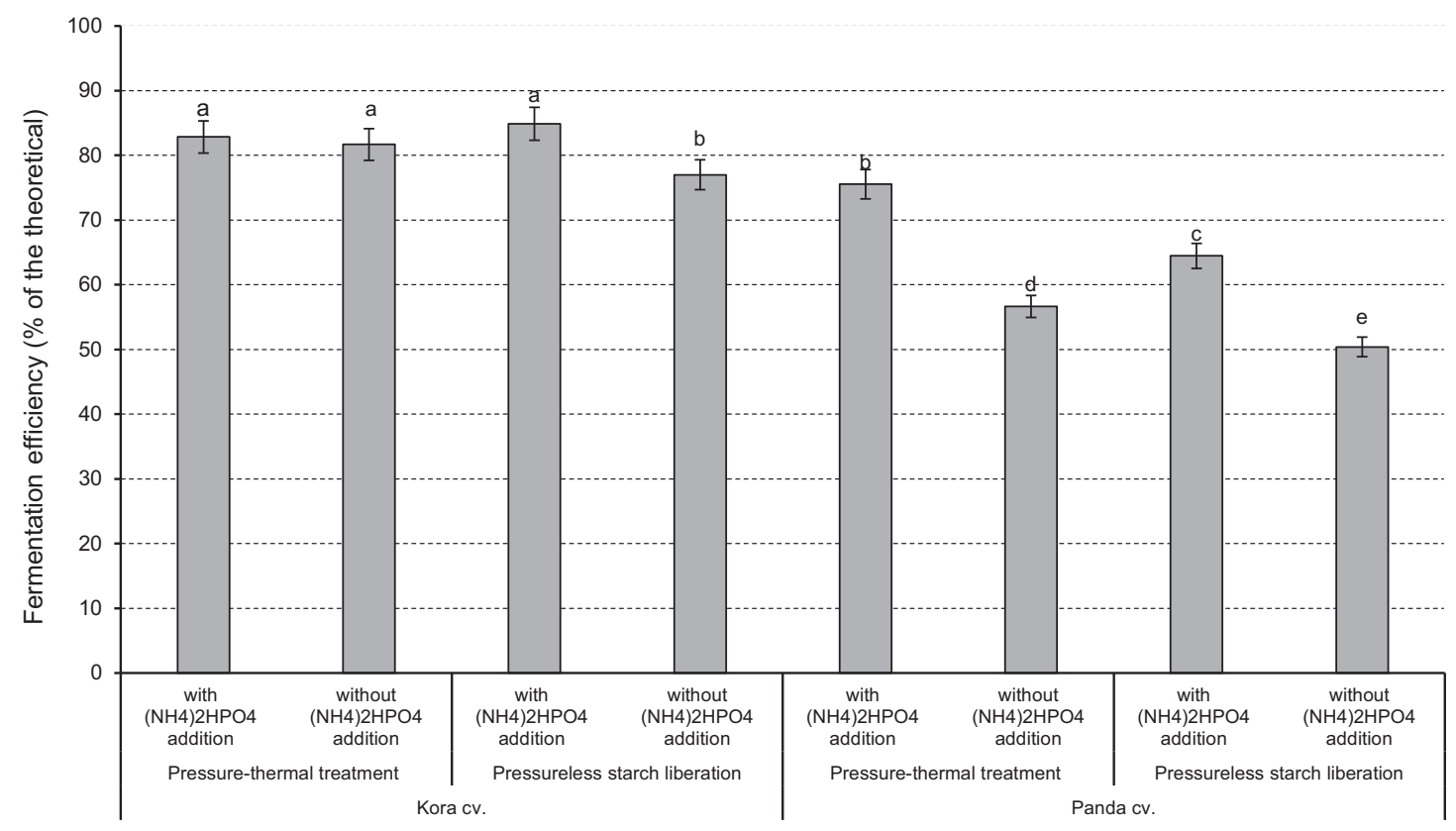

FIGURE 3. Fermentation efficiency in distillery mashes prepared from buckwheat grain. Different letters indicate significant differences $(p<0.05)$ between mean values. 
TABLE 4. Volatile compounds concentrations in the obtained distillates (mg/L alcohol 100\% vol.).

\begin{tabular}{|c|c|c|c|c|c|c|c|c|}
\hline \multirow{3}{*}{$\begin{array}{l}\text { Volatile } \\
\text { compounds }\end{array}$} & \multicolumn{4}{|c|}{ Kora cv. } & \multicolumn{4}{|c|}{ Panda cv. } \\
\hline & \multicolumn{2}{|c|}{ Pressure-thermal treatment } & \multicolumn{2}{|c|}{ Pressureless starch liberation } & \multicolumn{2}{|c|}{ Pressure-thermal treatment } & \multicolumn{2}{|c|}{ Pressureless starch liberation } \\
\hline & $\begin{array}{c}\text { with } \\
\left(\mathrm{NH}_{4}\right)_{2} \mathrm{HPO}_{4} \\
\end{array}$ & $\begin{array}{c}\text { without } \\
\left(\mathrm{NH}_{4}\right)_{2} \mathrm{HPO}_{4} \\
\end{array}$ & \begin{tabular}{c|} 
with \\
$\left(\mathrm{NH}_{4}\right)_{2} \mathrm{HPO}_{4}$ \\
\end{tabular} & \begin{tabular}{|c|} 
without \\
$\left(\mathrm{NH}_{4}\right)_{2} \mathrm{HPO}_{4}$ \\
\end{tabular} & $\begin{array}{c}\text { with } \\
\left(\mathrm{NH}_{4}\right)_{2} \mathrm{HPO}_{4} \\
\end{array}$ & $\begin{array}{c}\text { without } \\
\left(\mathrm{NH}_{4}\right)_{2} \mathrm{HPO}_{4} \\
\end{array}$ & $\begin{array}{c}\text { with } \\
\left(\mathrm{NH}_{4}\right)_{2} \mathrm{HPO}_{4} \\
\end{array}$ & $\begin{array}{c}\text { without } \\
\left(\mathrm{NH}_{4}\right)_{2} \mathrm{HPO}_{4} \\
\end{array}$ \\
\hline \multicolumn{9}{|c|}{ Carbonyl compounds } \\
\hline Acetaldehyde & $274.90 \pm 12.49^{\mathrm{d}}$ & $606.73 \pm 20.67^{\mathrm{a}}$ & $492.09 \pm 19.21^{\mathrm{b}}$ & $260.30 \pm 11.03^{\mathrm{d}}$ & $275.69 \pm 12.57^{d}$ & $535.81 \pm 24.58^{\mathrm{b}}$ & $404.50 \pm 13.45^{\mathrm{c}}$ & $208.71 \pm 9.87^{\mathrm{e}}$ \\
\hline Furfural & $6.12 \pm 0.31^{\mathrm{f}}$ & $22.94 \pm 1.29^{\mathrm{a}}$ & $7.55 \pm 0.56^{\mathrm{e}}$ & $17.95 \pm 1.12^{\mathrm{bc}}$ & $10.42 \pm 1.04^{d}$ & $18.81 \pm 1.24^{\mathrm{b}}$ & $10.91 \pm 0.79^{d}$ & $15.66 \pm 1.27^{\circ}$ \\
\hline 5-Methyl-2-furfural & $2.73 \pm 0.17^{\mathrm{d}}$ & $5.51 \pm 0.25^{\mathrm{a}}$ & $3.23 \pm 0.22^{\mathrm{c}}$ & $5.17 \pm 0.32^{\mathrm{a}}$ & $3.43 \pm 0.14^{c}$ & $4.38 \pm 0.24^{b}$ & $3.31 \pm 0.13^{\mathrm{c}}$ & $4.29 \pm 0.23^{\mathrm{b}}$ \\
\hline Acetone & n.d. & n.d. & n.d. & n.d. & $137.26 \pm 9.73^{\mathrm{b}}$ & $298.93 \pm 12.89^{\mathrm{a}}$ & n.d. & n.d. \\
\hline Diacetyl & $186.13 \pm 9.61^{\mathrm{h}}$ & $1635.83 \pm 26.58^{\mathrm{a}}$ & $606.00 \pm 12.60^{\mathrm{g}}$ & $902.92 \pm 17.30^{\mathrm{e}}$ & $843.85 \pm 14.39^{\mathrm{f}}$ & $1523.83 \pm 15.38^{\mathrm{b}}$ & $1061.72 \pm 16.17^{c}$ & $1021.00 \pm 12.10^{d}$ \\
\hline \multicolumn{9}{|c|}{ Esters } \\
\hline Ethyl acetate & $159.67 \pm 5.97^{\mathrm{e}}$ & $253.55 \pm 9.36^{\mathrm{a}}$ & $220.88 \pm 8.09^{\mathrm{b}}$ & $192.88 \pm 8.29^{c}$ & $175.50 \pm 7.55^{d}$ & $199.40 \pm 10.94^{c}$ & $174.97 \pm 7.50^{d}$ & $232.01 \pm 13.20^{\mathrm{b}}$ \\
\hline Isoamyl acetate & $5.82 \pm 0.18^{\mathrm{b}}$ & $5.65 \pm 0.27^{\mathrm{bc}}$ & n.d. & $4.74 \pm 0.17^{\mathrm{e}}$ & $7.43 \pm 0.34^{\mathrm{a}}$ & n.d. & $5.26 \pm 0.23^{\mathrm{cd}}$ & $5.02 \pm 0.22^{\mathrm{de}}$ \\
\hline Ethyl hexanoate & $1.39 \pm 0.08^{\mathrm{a}}$ & $0.18 \pm 0.02^{\mathrm{b}}$ & n.d. & $1.39 \pm 0.09^{\mathrm{a}}$ & n.d. & n.d. & n.d. & n.d. \\
\hline Ethyl lactate & n.d. & $3.66 \pm 0.17^{\mathrm{d}}$ & $2.01 \pm 0.13^{\mathrm{e}}$ & $82.06 \pm 3.21^{\mathrm{a}}$ & $1.24 \pm 0.08^{\mathrm{f}}$ & $4.07 \pm 0.24^{c}$ & $3.50 \pm 0.15^{\mathrm{d}}$ & $76.94 \pm 2.69^{b}$ \\
\hline Ethyl octanonate & $3.18 \pm 0.22^{\mathrm{c}}$ & $3.00 \pm 0.25^{\mathrm{c}}$ & $1.46 \pm 0.15^{\mathrm{e}}$ & $5.10 \pm 0.31^{\mathrm{a}}$ & $4.13 \pm 0.31^{\mathrm{b}}$ & $2.28 \pm 0.23^{\mathrm{d}}$ & $4.55 \pm 0.46^{\mathrm{ab}}$ & $5.43 \pm 0.52^{\mathrm{a}}$ \\
\hline Ethyl decanoate & $3.18 \pm 0.12^{\mathrm{c}}$ & $2.33 \pm 0.13^{\mathrm{d}}$ & $3.51 \pm 0.15^{\mathrm{b}}$ & $3.64 \pm 0.16^{\mathrm{b}}$ & $3.38 \pm 0.14^{\mathrm{bc}}$ & n.d. & $6.26 \pm 0.33^{\mathrm{a}}$ & $3.21 \pm 0.12^{\mathrm{c}}$ \\
\hline \multicolumn{9}{|c|}{ Alcohols } \\
\hline Methanol & $164.51 \pm 10.45^{\mathrm{c}}$ & $646.43 \pm 34.64^{a}$ & $639.37 \pm 33.98^{\mathrm{a}}$ & $268.08 \pm 16.81^{\mathrm{b}}$ & $175.84 \pm 9.58^{\mathrm{c}}$ & $689.38 \pm 38.94^{\mathrm{a}}$ & $688.72 \pm 38.87^{\mathrm{a}}$ & $294.56 \pm 19.46^{\mathrm{b}}$ \\
\hline 1-Propanol & $49.54 \pm 2.95^{\mathrm{d}}$ & $58.18 \pm 3.82^{\mathrm{c}}$ & $75.01 \pm 3.50^{\mathrm{a}}$ & $52.75 \pm 2.28^{c}$ & $63.06 \pm 3.31^{\mathrm{b}}$ & $68.18 \pm 3.82^{\mathrm{b}}$ & $57.97 \pm 2.47^{c}$ & $52.31 \pm 2.83^{\mathrm{c}}$ \\
\hline 2-Methyl-1-propanol & $1528.97 \pm 52.90^{b}$ & $876.93 \pm 27.69^{d}$ & $883.28 \pm 28.33^{\mathrm{d}}$ & $1223.49 \pm 62.34^{c}$ & $1708.54 \pm 70.85^{\mathrm{a}}$ & $847.80 \pm 44.78^{d}$ & $825.24 \pm 42.52^{\mathrm{d}}$ & $1493.45 \pm 49.35^{b}$ \\
\hline 1-Butanol & $7.13 \pm 0.21^{\mathrm{b}}$ & $8.38 \pm 0.36^{\mathrm{a}}$ & $9.14 \pm 0.41^{\mathrm{a}}$ & $4.97 \pm 0.26^{\mathrm{d}}$ & $7.28 \pm 0.33^{b}$ & $8.78 \pm 0.38^{\mathrm{a}}$ & $6.20 \pm 0.22^{\mathrm{c}}$ & $5.09 \pm 0.21^{\mathrm{d}}$ \\
\hline 3-Methyl-1-butanol & $2453.93 \pm 65.39^{\mathrm{a}}$ & $1758.98 \pm 35.90^{c}$ & $1648.14 \pm 34.81^{\mathrm{d}}$ & $2128.23 \pm 22.82^{b}$ & $2471.47 \pm 27.15^{\mathrm{a}}$ & $1574.92 \pm 17.49^{e}$ & $1785.04 \pm 18.50^{c}$ & $2168.36 \pm 26.84^{b}$ \\
\hline Phenylethyl alcohol & $1588.88 \pm 48.89^{\mathrm{b}}$ & $1025.09 \pm 22.51^{\mathrm{e}}$ & $755.89 \pm 15.60^{\mathrm{g}}$ & $1720.88 \pm 32.08^{\mathrm{a}}$ & $1193.76 \pm 19.38^{c}$ & $974.32 \pm 27.43^{\mathrm{f}}$ & $1141.49 \pm 21.15^{\mathrm{d}}$ & $1581.76 \pm 48.18^{b}$ \\
\hline \multicolumn{9}{|c|}{ Acids } \\
\hline Acetic acid & $43.98 \pm 3.43^{\mathrm{d}}$ & $32.23 \pm 2.22^{\mathrm{e}}$ & $71.10 \pm 4.11^{\mathrm{c}}$ & $138.56 \pm 7.86^{\mathrm{a}}$ & $84.30 \pm 5.43^{b}$ & $72.37 \pm 4.24^{c}$ & $130.84 \pm 8.08^{\mathrm{a}}$ & $142.60 \pm 8.26^{\mathrm{a}}$ \\
\hline Isobutyric acid & $5.54 \pm 0.35^{\mathrm{e}}$ & $1.74 \pm 0.07^{g}$ & $99.33 \pm 3.93^{b}$ & $492.78 \pm 19.28^{a}$ & $6.58 \pm 0.06^{d}$ & n.d. & $2.84 \pm 0.08^{\mathrm{f}}$ & $10.01 \pm 0.12^{\mathrm{c}}$ \\
\hline 2-Methylhexanoic acid & $7.54 \pm 0.25^{\mathrm{b}}$ & $5.23 \pm 0.15^{\mathrm{d}}$ & $3.32 \pm 0.08^{\mathrm{f}}$ & $8.66 \pm 0.47^{a}$ & $6.19 \pm 0.22^{\mathrm{c}}$ & $3.94 \pm 0.08^{\mathrm{e}}$ & $3.29 \pm 0.13^{f}$ & $7.38 \pm 0.34^{\mathrm{b}}$ \\
\hline Octanoic acid & $7.91 \pm 0.29^{\mathrm{a}}$ & $8.16 \pm 0.32^{\mathrm{a}}$ & $4.89 \pm 0.24^{\mathrm{d}}$ & $3.13 \pm 0.15^{\mathrm{e}}$ & $7.19 \pm 0.32^{\mathrm{b}}$ & $5.65 \pm 0.27^{c}$ & $8.38 \pm 0.34^{\mathrm{a}}$ & $6.83 \pm 0.28^{\mathrm{b}}$ \\
\hline
\end{tabular}

Results expressed as mean values \pm SE $(n=3)$; values with different superscript letters in the same row are significantly different $(p<0.05)$; n.d. - not detected.

late obtained from mash prepared from the Panda cultivar, prepared with the PLS method with $\left(\mathrm{NH}_{4}\right)_{2} \mathrm{HPO}_{4}$ supplementation. It was observed that spirits from previously steamed raw material and supplemented with nutrients for yeast contained significantly $(\mathrm{p}<0.05)$ lower concentrations of acetaldehyde than those without the addition of $\left(\mathrm{NH}_{4}\right)_{2} \mathrm{HPO}_{4}$ (Table 4). It can be hypothesized that the pressure-thermal treatment of buckwheat grain leads to an impoverishment of the fermentation medium with nutrients, and that in order to prevent the suppression of the enzymatic activity of yeast (especially alcohol dehydrogenase activity responsible for the reduction of acetaldehyde to ethyl alcohol) it is advisable to supplement the fermentation medium with minerals. The opposite relation was observed in the composition of distillates from mashes prepared with the PLS method. The distillates from mashes with the addition of nutrients for yeast contained higher concentrations of acetaldehyde than the those from non-supplemented fermented samples $(\mathrm{p}<0.05)$.

Furfural and 5-methyl-2-furfural, which are mainly formed during the dehydration of pentoses and hexoses at elevated temperatures (e.g. during pressure thermal-treatment of starchy raw materials), are among the heterocyclic aldehydes occurring in agricultural distillates [Lee et al., 2001]. Furfural also arises during distillation involving Maillard reactions, hence its synthesis in the heated pot still is probably a fundamental factor causing its successive increase. Furfural, with an aroma resembling that of grain, also occurs at concentrations of as much as $20-30 \mathrm{mg} / \mathrm{L}$ in Scotch malt 
whiskies [Lyons, 2003]. A study conducted by Pielech-Przybylska et al. [2017] showed high concentrations of furfural, between $79.70 \pm 2.21$ and $225.81 \pm 6.48 \mathrm{mg} / \mathrm{L}$ alcohol $100 \%$ vol., in the distillates obtained from barley grain of the Karakan variety used as raw material and barley Munich malt as a source of amylolytic enzymes for starch hydrolysis. In turn, when the hydrolysis of barley starch was carried out using enzyme preparations, the concentrations of the furfural were lower and ranged from $43.53 \pm 1.23$ to $95.50 \pm 2.42 \mathrm{mg} / \mathrm{L}$ alcohol $100 \%$ vol.

In the distillates obtained in our study, the concentrations of furfural were lower and ranged from $6.12 \pm 0.31$ to $22.94 \pm 1.29 \mathrm{mg} / \mathrm{L}$ alcohol $100 \%$ vol. Both limit values determined in samples of the distillates obtained from mashes prepared by pressure-thermal treatment of buckwheat grain from the Kora cultivar, were differentiated only by the addition or not of nutrients for yeast. Despite statistically significant differences in the furfural content (Table 4), pressure-thermal treatment was observed to have no clear effect on its concentrations. The content of 5-methyl-2-furfural was much lower compared to the amounts of furfural $(\mathrm{p}<0.05)$, and ranged from $2.73 \pm 0.17$ to $5.51 \pm 0.25 \mathrm{mg} / \mathrm{L}$ alcohol $100 \%$ vol.. All the distillates from the samples supplemented with nutrients for yeast contained significantly $(p<0.05)$ lower concentrations of furfural and 5-methyl-2-furfural compared to the spirits from mashes without the addition of $\left(\mathrm{NH}_{4}\right)_{2} \mathrm{HPO}_{4}$.

The presence of acetone was only observed in the distillates obtained from the mashes based on Panda buckwheat cultivar, prepared by steaming the raw material. The main substrate for acetone synthesis is acetyl-CoA, produced by yeast and bacteria from acetic acid which, in turn, is a result of Maillard reactions that occur when mashes are prepared by pressure-thermal treatment of raw material [Pielech-Przybylska et al., 2019].

Another ubiquitous compound in alcoholic beverages is vicinal diketone, 2,3-butanedione (diacetyl) with a buttery aroma [Stewart, 2017]. Diacetyl is formed as a by-product of valine biosynthesis in Saccharomyces yeast. The amount formed varies greatly depending on the yeast strain used, wort quality (e.g., free amino nitrogen (FAN) content, $\mathrm{pH}$, and valine content), and fermentation conditions (e.g., temperature, pressure, and yeast pitching rate) [Kobayashi et al., 2005]. The distillates obtained in our study contained various concentrations of diacetyl, ranging from $186.13 \pm 9.61 \mathrm{mg} / \mathrm{L}$ alcohol $100 \%$ vol. to $1635.83 \pm 26.58 \mathrm{mg} / \mathrm{L}$ alcohol $100 \%$ vol. Significantly higher $(\mathrm{p}<0.05)$ concentrations of diacetyl were determined in the majority of distillates from mashes prepared by pressure-thermal treatment and without supplementation with $\left(\mathrm{NH}_{4}\right)_{2} \mathrm{HPO}_{4}$. Kobayashi et al. [2005] reported that fermentation conditions promoting rapid yeast growth enhance diacetyl production if the free amino nitrogen content of the wort is insufficient. This may explain the higher amounts of diacetyl in the distillates from mashes not supplemented with $\left(\mathrm{NH}_{4}\right)_{2} \mathrm{HPO}_{4}$

The concentrations of diacetyl were higher in the tested buckwheat distillates than in the samples of spirits obtained from other starchy raw materials, e.g. from rye and barley grains, and the corresponding malts (from approx. 3 to $5 \mathrm{mg} / \mathrm{L}$ alcohol 100\% vol.) [Balcerek et al., 2016]. Sen- sory analysis of buckwheat-based beer carried out by Phiarais et al. [2010] showed a very distinct "buttery" flavor, which is imparted by vicinal diketones, i.e. 2,3-butanedione and 2,3-pentanedione. Although these compounds are commonly considered undesirable in terms of the quality of beer, the results showed that buckwheat beer was acceptable for all attributes (aroma, purity of taste, and bitterness). Taking into consideration the results of our study and findings reported by Phiarais et al. [2010], it can be hypothesized that diacetyl is characteristic for buckwheat fermented (including distilled) beverages.

Esters are an important group of flavor compounds found in spirits. They are largely formed during the active phase of fermentation by the enzymatic condensation of organic acids with alcohols. Aroma constituents of major importance include: ethyl acetate (solvent-like aroma), isoamyl acetate (banana aroma), isobutyl acetate (fruity aroma), phenylethyl acetate (roses and honey aroma), ethyl hexanoate (sweet apple aroma), and ethyl octanoate (sour apple aroma) [Stewart, 2017]. Grain distillates of agricultural origin also contain other esters, such as ethyl propanoate, ethyl butyrate, ethyl pentanoate, ethyl heptanoate, ethyl nonanoate, ethyl decanoate, ethyl undecanoate, and ethyl dodecanoate [Plutowska et al., 2010]. In the analyzed distillates, the predominant ester was ethyl acetate, which was present in concentrations from $159.67 \pm 5.97$ to $253.55 \pm 9.36 \mathrm{mg} / \mathrm{L}$ alcohol $100 \%$ vol. The distillates had also small amounts of isoamyl acetate, as well as esters of higher carboxylic acids and ethanol, i.e., ethyl hexanoate, ethyl octanoate, and ethyl decanoate. The significant differences observed in the concentrations of these esters were not strictly associated with the use of different buckwheat cultivars or processing conditions. The profiles of esters and their concentrations in the buckwheat-based distillates were similar to those determined in other cereal distillates [Balcerek et al., 2016; Pielech-Przybylska et al., 2017].

Higher alcohols are an important group of fermentation by-products, in terms of the quantity but also the sensory characteristics of agricultural distillates. They are represented mainly by $n$-propanol, isobutanol, and amyl alcohol (with its isomers, i.e., 2-methyl-1-butanol and 3-methyl-1-butanol). Regulation of the biosynthesis of higher alcohols is complex, since they are either produced as by-products of amino acid metabolism or via pyruvate and ethanol produced during carbohydrate metabolism [Russell, 2003]. These compounds play an important role in the formation of flavor qualities in spirits including whisky and others. Malt Scotch whiskies are rich in higher alcohols, with contents often well over $2 \mathrm{~g} / \mathrm{L}$ [Lyons, 2003]. According to the recommendations of the Polish Standard [PN-A-79523, 2002], the maximum concentration of higher alcohols in agricultural distillates used for Starka production is $5 \mathrm{~g} / \mathrm{L}$ absolute alcohol. In the buckwheat-based raw spirits obtained in our study, the most abundant higher alcohol was 3-methyl-1-butanol. In addition, 2-methyl-1-propanol and phenylethyl alcohol were found at relatively high concentrations, compared with the other cereal-based distillates [Balcerek et al., 2016; Pielech-Przybylska et al., 2017]. Previous studies have identified 2-phenylethanol as a representative aroma compound in buckwheat-based alcoholic 
TABLE 5. Sensory assessment of buckwheat distillates.

\begin{tabular}{|c|c|c|c|c|c|c|c|c|}
\hline \multirow{3}{*}{ Sensory attributes } & \multicolumn{4}{|c|}{ Kora cv. } & \multicolumn{4}{|c|}{ Panda cv. } \\
\hline & \multicolumn{2}{|c|}{ Pressure-thermal treatment } & \multicolumn{2}{|c|}{ Pressureless starch liberation } & \multicolumn{2}{|c|}{ Pressure-thermal treatment } & \multicolumn{2}{|c|}{ Pressureless starch liberation } \\
\hline & $\begin{array}{c}\text { with } \\
\left(\mathrm{NH}_{4}\right)_{2} \mathrm{HPO}_{4}\end{array}$ & $\begin{array}{c}\text { without } \\
\left(\mathrm{NH}_{4}\right)_{2} \mathrm{HPO}_{4}\end{array}$ & $\begin{array}{c}\text { with } \\
\left(\mathrm{NH}_{4}\right)_{2} \mathrm{HPO}_{4}\end{array}$ & \begin{tabular}{|c|} 
without \\
$\left(\mathrm{NH}_{4}\right)_{2} \mathrm{HPO}_{4}$ \\
\end{tabular} & $\begin{array}{c}\text { with } \\
\left(\mathrm{NH}_{4}\right)_{2} \mathrm{HPO}_{4} \\
\end{array}$ & $\begin{array}{c}\text { without } \\
\left(\mathrm{NH}_{4}\right)_{2} \mathrm{HPO}_{4}\end{array}$ & \begin{tabular}{|c} 
with \\
$\left(\mathrm{NH}_{4}\right)_{2} \mathrm{HPO}_{4}$
\end{tabular} & $\begin{array}{c}\text { without } \\
\left(\mathrm{NH}_{4}\right)_{2} \mathrm{HPO}_{4}\end{array}$ \\
\hline Color (max. 2 pts) & $2.0 \pm 0.0^{\mathrm{a}}$ & $2.0 \pm 0.0^{\mathrm{a}}$ & $2.0 \pm 0.0^{\mathrm{a}}$ & $2.0 \pm 0.0^{\mathrm{a}}$ & $2.0 \pm 0.0^{\mathrm{a}}$ & $2.0 \pm 0.0^{\mathrm{a}}$ & $2.0 \pm 0.0^{\mathrm{a}}$ & $2.0 \pm 0.0^{\mathrm{a}}$ \\
\hline Clearness (max. 2 pts) & $2.0 \pm 0.0^{\mathrm{a}}$ & $2.0 \pm 0.0^{\mathrm{a}}$ & $2.0 \pm 0.0^{\mathrm{a}}$ & $2.0 \pm 0.0^{\mathrm{a}}$ & $2.0 \pm 0.0^{\mathrm{a}}$ & $2.0 \pm 0.0^{\mathrm{a}}$ & $2.0 \pm 0.0^{\mathrm{a}}$ & $2.0 \pm 0.0^{\mathrm{a}}$ \\
\hline Odor (max. 4 pts) & $3.0 \pm 0.5^{\mathrm{a}}$ & $2.5 \pm 0.5^{\mathrm{ab}}$ & $2.0 \pm 0.3^{\mathrm{bc}}$ & $1.5 \pm 0.2^{\mathrm{c}}$ & $3.5 \pm 0.5^{\mathrm{a}}$ & $3.0 \pm 0.5^{\mathrm{a}}$ & $2.5 \pm 0.2^{\mathrm{b}}$ & $2.5 \pm 0.2^{\mathrm{b}}$ \\
\hline Taste (max. 12 pts) & $8.0 \pm 0.5^{\mathrm{a}}$ & $7.5 \pm 0.5^{\mathrm{a}}$ & $4.5 \pm 0.5^{\mathrm{c}}$ & $4.0 \pm 0.5^{\mathrm{c}}$ & $8.0 \pm 0.5^{\mathrm{a}}$ & $8.5 \pm 0.5^{\mathrm{a}}$ & $5.5 \pm 0.2^{\mathrm{b}}$ & $5.5 \pm 0.2^{\mathrm{b}}$ \\
\hline Overall (max. 20 pts) & $15.0 \pm 0.5^{\mathrm{ab}}$ & $14.0 \pm 0.5^{b}$ & $10.5 \pm 0.4^{\mathrm{d}}$ & $9.5 \pm 0.4^{\mathrm{e}}$ & $15.5 \pm 0.4^{\mathrm{a}}$ & $15.5 \pm 0.4^{\mathrm{a}}$ & $12.0 \pm 0.2^{\mathrm{c}}$ & $12.0 \pm 0.2^{\mathrm{c}}$ \\
\hline
\end{tabular}

Results expressed as mean values \pm SE $(n=3)$; values with different superscript letters in the same row are significantly different $(p<0.05)$; pts - points.

beverages including mead [Wintersteen et al., 2005] and beer [Deželak et al., 2014].

In our analysis of the qualitative and quantitative composition of volatile compounds in the buckwheat distillates, attention was also given to the relationship between the chemical composition of the sweet mashes (the content of reducing sugars) (Table 2) and the concentration of volatiles (Table 4). As a result, it was observed that the distillates from mashes prepared by pressure-thermal treatment, with initially lower fermentable sugars content, contained lower amounts of aldehydes and diacetyl, but higher levels of 2-methyl-1-propanol and 3-methyl-1-butanol. Kłosowski et al. [2015] observed the effect of the availability of sugars released during hydrolysis of starchy raw materials on the concentration of higher alcohols during the fermentation process. Their results indicate that the highest glucose content in maize mashes resulted in significantly higher isobutanol and 2-methyl-1-butanol contents during the initial stage of fermentation. Moreover, the maize-based distillates contained higher final total content of fusel alcohols compared to rye and amaranth-based distillates.

One of the undesirable compounds in spirit distillates is methanol, which is generated through the hydrolysis of methylated pectins present in plants and fruits. While methanol does not directly affect the flavor of the distillate, it is subjected to restrictive controls, owing to its high toxicity [Adam \& Versini, 1996]. The tested distillates in our study contained methyl alcohol at concentrations between $164.51 \pm 10.45$ and $689.38 \pm 38.94 \mathrm{mg} / \mathrm{L}$ alcohol $100 \%$ vol. There were no clear effects related to the buckwheat cultivar, the method of starch liberation or supplementation with nutrients for yeast on methanol content. The results of our previous study showed that the agricultural distillates obtained from rye and barley grains and the corresponding malts contained methanol in concentrations between $42.5 \pm 6.5 \mathrm{mg} / \mathrm{L}$ and $198.1 \pm 17.3 \mathrm{mg} / \mathrm{L}$ alcohol $100 \%$ vol. [Balcerek et al., 2016]. In turn, Pielech-Przybylska et al. [2017] observed methanol contents in barley distillates at between approx. 33 and $73 \mathrm{mg} / \mathrm{L}$ alcohol $100 \%$ vol. Moreover, they were higher in the samples obtained from mashes prepared by the pressure-thermal than with the PLS method. While EU Regulation no. 110/2008 [Regulation (EC) No 110/2008] defines acceptable concentrations of methanol in ethyl alcohols of agricultural origin (rectified spirit), wine spirits, and fruit spirits, it does not set any limits on the content of this compound in distillates of agricultural origin.

The final group of volatiles found in the tested distillates were volatile acids, among which acetic acid was predominant. Contaminating bacteria can alter the normal profiles of organic acids. Lactobacilli are very ethanol-tolerant and are capable of very rapid growth in distillery mashes. Increases in lactic and acetic acids are observed when there is contamination and these acids can inhibit the growth of yeast if produced in excess. Concentrations of lactic acid over $0.8 \%(\mathrm{w} / \mathrm{v})$ and of acetic acid over $0.05 \%(\mathrm{w} / \mathrm{v})$ negatively affect the growth of yeast. In addition, low $\mathrm{pH}$ can affect glucoamylase activity against residual dextrin. Bacterial contamination always means loss of ethanol. During fermentation, it has been observed that there is an increase in C6-C10 and a considerable decrease in C12-C18:3 acids as consequence of yeast metabolism [Russel, 2003]. The application of pressureless treatment in our study resulted in significantly higher concentrations, especially of acetic acid $(\mathrm{p}<0.05)$, compared to the pressure-thermal method. In the majority of distillates obtained by the pressure-thermal treatment of raw material, the concentrations of this compound did not exceed the recommended limit for agricultural distillates from cereals, i.e., $0.1 \mathrm{~g} / \mathrm{L}$ alcohol $100 \%$ vol. [Polish Standard PN-A-79523, 2002]. In contrast, the majority of distillates from both cultivars of buckwheat processed with the PLS method exceeded the permissible content of acetic acid by approx. $40 \%$. The results of chromatographic analysis also showed the presence of other acids, such as isobutyric, 2-methylhexanoic, and octanoic. It is important to note the very high concentrations of isobutyric acid in the distillates obtained after the fermentation of Kora cultivar-based mashes, prepared with the PLS method, which were characterized as having a lower $\mathrm{pH}$ after completed fermentation (Table 3). Isobutyric acid was at the level of $99.33 \pm 3.93 \mathrm{mg} / \mathrm{L}$ alcohol $100 \%$ vol. in the distillate from mash with the addition of $\left(\mathrm{NH}_{4}\right)_{2} \mathrm{HPO}_{4}$, whereas in the distillate without supplementation its concentration reached the very high level of $492.78 \pm 19.28 \mathrm{mg} / \mathrm{L}$ alcohol $100 \%$ vol. $(p<0.05)$. Thus, the results obtained in our study indicate that the pressureless method of preparing dis- 
tillery mashes carries the risk of microbial contaminations, which may reduce the quality of the distillates.

\section{Sensory analysis of distillates}

The results of sensory evaluation of the tested buckwheat distillates are presented in Table 5. All of the tested samples were assessed by the judges as being clear and colorless, as is characteristic of fresh distillates, and obtained the highest scores for these visual properties (2 pts). Significant differences were observed in terms of odor $(p<0.05)$. The least pleasant, pungent odor was attributed to the distillate from the Kora buckwheat cultivar, which was previously treated with the PLS method, and without the addition of $\left(\mathrm{NH}_{4}\right)_{2} \mathrm{HPO}_{4}$ (this mash had the lowest $\mathrm{pH}$ after fermentation). It received only $1.5 \pm 0.2$ of the possible 4 points for aroma. The distillate from the same cultivar, also processed with the PLS but supplemented with $\left(\mathrm{NH}_{4}\right)_{2} \mathrm{HPO}_{4}$, was assessed similarly. These samples were also judged to have an acrid taste and unharmonized aroma, as evidenced by the lowest taste ratings compared to other samples. Their overall sensory quality was the lowest and varied between $9.5 \pm 0.4$ and $10.5 \pm 0.4$ points (on a 20-point scale). The distillates obtained from the Panda cultivar using the PLS method were rated as not being very pleasant in smell and taste, although they obtained statistically significantly higher scores than analogous distillates from the Kora cultivar. The best rated distillates were those obtained from both cultivars when the mashes were prepared by pressure-thermal treatment. They were characterized by a pleasant aroma (odor) and a well-harmonized taste, characteristic of cereal distillates.

Despite the differences in the sensory quality of the buckwheat distillates, correlated mainly with the raw material processing method, the tasting panel considered that the majority of the buckwheat-based distillates were characterized by interesting organoleptic features and a specific aroma and flavor, defined as characteristic of the processed raw material. It was suggested that the application of additional treatments, such as re-distillation with separation of the head and tail fractions, and possibly ageing with wood, could allow producing interesting, original spirit beverages.

\section{CONCLUSION}

This study has demonstrated that to obtain a high yield of buckwheat distillate with appropriate organoleptic features, it is necessary to select the appropriate method of raw material pretreatment, including starch liberation, and enzymes for hydrolysis, possibly including supportive enzyme preparations, such as xylanase, as well as to supplement the mashes with mineral nutrients for yeast.

The chemical compositions of two buckwheat cultivars, Kora and Panda, were assessed to determine their suitability for use in the production of agricultural distillate (raw spirit). Both cultivars contained similar amounts of starch, while the second contained a significantly higher content of reducing sugars. However, the sweet mashes obtained after digestion of grain from the Panda cultivar with amylolytic enzyme preparations had a higher content of dextrin, which may indicate more difficult starch hydrolysis than in the case of the Kora cultivar. Of the tested methods of starch liberation, pressure-thermal treatment, was found to be more efficient in terms of ethanol biosynthesis, especially for the Panda cultivar. A beneficial effect on fermentation efficiency was also observed in the case of mashes supplemented with $\left(\mathrm{NH}_{4}\right)_{2} \mathrm{HPO}_{4}$. In order to boost fermentation efficiency and improve the quality of the obtained distillates, further research is necessary to study the conversion of buckwheat grain into agricultural distillate, taking into consideration the conditions of mashing and the fermentation process, as well as antimicrobial protection. Moreover, separation of the head and tail fractions which contain undesirable compounds in terms of the sensory qualities of the buckwheat distillates should be carried out.

There is increasing interest in niche craft products from both micro-distilleries and large spirit plants, which are considering the use of new raw materials, while taking into account social attachments and tradition. Selection of the factors in buckwheat distillation identified in this study opens the way for using grain from this pseudo-cereal in the production of original distillates with a specific aroma, flavor, and raw material identity.

\section{REFERENCES}

1. Adam, L., Versini, G. (1996). A study on the possibilities to lower the content of methyl-alcohol in eaux-de-vie de fruits; European Commission: Brussels, Belgium, pp. 1-8, [https://op.europa.eu/ en/publication-detail/-/publication/0b908be6-2673-45a5-8c2fb3b6abclaa37] (accessed on 12 September 2019).

2. AOAC (1995). Official Methods of Analysis of AOAC International. Method $960.52,16^{\text {th }}$ edition. AOAC International, Maryland, USA.

3. Aoki, M., Koizumi, N. (1986). Organoleptic properties of the volatile components of buckwheat flour and their changes during storage after milling. Nippon Shokuhin Kogyo Gakkaishi - Journal of the Japanese Society for Food Science and Technology, 33(11), 769-772.

4. Balcerek, M., Pielech-Przybylska, K., Dziekońska-Kubczak, U., Patelski, P., Strąk, E., (2016). Fermentation results and chemical composition of agricultural distillates obtained from rye and barley grains and the corresponding malts as a source of amylolytic enzymes and starch. Molecules, 21(10), art. no. 130.

5. Banerjee, S., Kundu, D. (2013). A comparative overview of ethanol production from cereal grains and potato by enzymatic treatment. International Journal of Research in Engineering \& Advanced Technology, 1(2), 1-11.

6. Bonafaccia, G., Marocchini, M., Kreft, I. (2003). Composition and technological properties of the flour and bran from common and tartary buckwheat. Food Chemistry, 80(1), 9-15.

7. Chida, M., Sone, Y., Tamura, H. (2004). Aroma characteristics of stored tobacco cut leaves analyzed by a high vacuum distillation and canister system. Journal of Agricultural and Food Chemistry, 52(26), 7918-7924.

8. COBORU (2019). Centralny Ośrodek Badania Odmian Roślin Uprawnych (Krajowy Rejestr (KR), [http://www.coboru.pl/Polska/Rejestr/rejestr_KR.aspx] (accessed on 10 September 2019).

9. Deželak, M., Zarnkow, M., Becker, T., Košir, I.J. (2014). Processing of bottom-fermented gluten-free beer-like beverages based 
on buckwheat and quinoa malt with chemical and sensory characterization. Journal of the Institute of Brewing, 120(4), 360-370.

10. Dziadek, K., Kopeć, A., Pastucha, E., Piątkowska, E., Leszczyńska, T., Pisulewska, E., Witkowicz, R., Francik, R. (2016). Basic chemical composition and bioactive compounds content in selected cultivars of buckwheat whole seeds, dehulled seeds, and hulls. Journal of Cereal Science, 69, 1-8.

11. EFSA Journal (2004). Opinion of the Scientific Panel on Dietetic Products, Nutrition and Allergies on a request from the Commission related to a notification from CEPS on distillates made from cereals pursuant to Article 6 paragraph 11 of Directive 2000/13/EC. 130, 1-6.

12. Haros, C.M., Sanz-Penella, J.M. (2017). Food uses of whole pseudocereals. In C.M. Haros, R. Schonlechner (Eds.), Pseudocereals: Chemistry and Technology, Wiley-Blackwell, Hoboken, New Jersey, USA, pp. 163-192.

13. Im, J.S., Huff, H.E., Hsieh, F.H. (2003). Effect of processing conditions on the physical and chemical properties of buckwheat grit cakes. Journal of Agricultural and Food Chemistry, 5l(3), 659-666.

14. Janes, D., Kantar, D., Kreft, S., Prosen, H. (2009). Identification of buckwheat (Fagopyrum esculentum Moench) aroma compounds with GC-MS. Food Chemistry, 112(1), 120-124.

15. Kłosowski, G., Mikulski, D., Macko, D., Miklaszewska, B., Kotarska, K., Czupryński, B. (2015). Influence of various yeast strains and selected starchy raw materials on production of higher alcohols during the alcoholic fermentation process. European Food Research and Technology, 240(1), 233-242.

16. Kobayashi, K., Kusaka, K., Takahashi, T., Sato, K.(2005). Method for the simultaneous assay of diacetyl and acetoin in the presence of $\alpha$-acetolactate: Application in determining the kinetic parameters for the decomposition of $\alpha$-acetolactate. Journal of Bioscience and Bioengineering, 99(50), 502-507.

17. Kotarska, K., Czupryński, B., Kłosowski, G. (2006). Effect of various activators on the course of alcoholic fermentation. Journal of Food Engineering, 77(4), 965-971.

18. Lee, M.K.-Y., Paterson, A., Piggott, J.R., Richardson, G.D. (2001). Origins of flavour in whiskies and a revised flavour wheel: A review. Journal of the Institute of Brewing, 107(5), 287-313.

19. Lyons, T.P. (2003). Production of Scotch and Irish whiskies: Their history and evolution. In K.A. Jacques, T.P. Lyons, D.R. Kelsall (Eds.), The Alcohol Textbook, 4th ed., Alltech Inc., Nicholasville, KY, USA, pp. 193-206.

20. Miller, G.L. (1959). Use of dinitrosalicylic acid reagent for determining reducing sugars. Analytical Chemistry, 31 (3), 426-428.

21. Muthaiyan, A., Limayem, A., Rücke, S. (2011). Antimicrobial strategies for limiting bacterial contaminants in fuel bioethanol fermentations. Progress in Energy and Combustion Science, 37, 351-370.

22. Narendranath, N.V. (2003). Bacterial contamination and control in ethanol production. In K.A. Jacques, T.P. Lyons, D.R. Kelsall (Eds.), The Alcohol Textbook, 4th ed., Alltech Inc., Nicholasville, KY, USA, pp. 287-291.

23. Nicol, D.A. (2003). Rum. In A.G.H. Lea, J.R. Piggott (Eds.), Fermented Beverage Production; Kluwer Academic/Plenum Publishers, New York, NY, USA, p. 271.

24. Phiarais, B.P.N., Mauch, A., Schehl, B.D., Zarnkow, M., Gastl, M., Herrmann, M., Zaninni, E., Arendt, E.K. (2010). Processing of top fermented beer brewed from $100 \%$ buckwheat malt with sensory and analytical characterization. Journal of the Institute of Brewing, 116(3), 265-274.

25. Pielech-Przybylska, K., Balcerek, M., Dziekońska-Kubczak, U., Pacholczyk-Sienicka, B., Ciepielowski, G., Albrecht, Ł., Patelski, P. (2019). The role of Saccharomyces cerevisiae yeast and lactic acid bacteria in the formation of 2-propanol from acetone during fermentation of rye mashes obtained using thermal-pressure method of starch liberation. Molecules, 24(3), art. no. 610.

26. Pielech-Przybylska, K., Balcerek, M., Nowak, A., Wojtczak, M., Czyżowska, A., Dziekońska-Kubczak, U., Patelski, P. (2017). The effect of different starch liberation and saccharification methods on the microbial contaminations of distillery mashes, fermentation efficiency, and spirits quality. Molecules, 22(10), art. no. 1647.

27. Plutowska, B., Biernacka, P., Wardencki, W. (2010). Identification of volatile compounds in raw spirits of different organoleptic quality. Journal of the Institute of Brewing, 116(4), 433-439.

28. Polish Standard PN-A-79523 (2002). Agricultural Distillate. Polish Committee for Standardization, Warsaw, Poland, pp. 1-7.

29. Polish Standard PN-EN ISO 10520 (2002). Native starch. Determination of starch content. Ewers Polarimetric Method. Polish Committee for Standardization: Warsaw, Poland, pp. 1-13.

30. Regulation (EC) No 110/2008 of the European Parliament and of the Council of 15 January 2008 on the Definition, Description, Presentation, Labelling and the Protection of Geographical Indications of Spirit Drinks and Repealing Council Regulation (EEC) No 1576/89; Official Journal of the European Union: Luxembourg, p. L 39/16

31. Russell, I. (2003). Understanding yeast fundamentals. In K.A. Jacques, T.P. Lyons, D.R. Kelsall (Eds.), The Alcohol Textbook, 4th ed., Alltech Inc., Nicholasville, KY, USA, pp. 85-120.

32. Sakaida, H., Nakahara, N., Watashi, N., Kai, T., Nakashima, Y., Sakakibara, Y., Nishiyana, K., Fukuda, N., Suiko, M. (2003). Characteristic flavor of buckwheat Shochu and comparison of volatile compounds from variety cereal Shochu. Nippon shokuhin Kagaku Kogaku Kaishi - Journal of the Japanese Society for Food Science and Technology, 50(12), 555-562.

33. Stankiewicz, C. (2004). Effect of sowing density, herbicides and harrowing application on yield and content of total protein and starch in 'Wanad' spring triticale kernels. Acta Scientiarum Polonorum, Agricultura, 3(2), 77-88 (in Polish).

34. Starowicz, M., Koutsidis, G., Zieliński, H. (2018). Sensory analysis and aroma compounds of buckwheat containing products - a review. Critical Reviews In Food Science And Nutrition, 58(11), 1767-1779.

35. Stempińska K., Soral-Smietana M. (2006). Chemical compounds and physicochemical estimation of buckwheat grains Comparison of three Polish varieties. Żywność. Nauka. Technologia. Jakość, 2(47), Suppl., 348-359 (in Polish; English abstract).

36. Stewart, G.G. (2017). The production of secondary metabolites with flavour potential during brewing and distilling wort fermentations. Fermentation - Basel, 3(4), art. no. 63.

37. Tešević, V., Nikićević, N., Jovanović, A., Djoković, D., Vujisić, L., Vučković, I., Bonić, M. (2005) Volatile components from old plum brandies. Food Technology and Biotechnology, 43(4), $367-372$. 
38. Wintersteen, C.L., Andrae, L.M., Engeseth, N.J. (2005). Effect of heat treatment on antioxidant capacity and flavor volatiles of mead. Journal of Food Science, 70(2), 119-126.

39. Young, S. (Ed.) (1922). Distillation Principles and Processes. Macmillian and Co., London, pp. 58, 146, 190, 220 [http://www. archive.org/details/distillationprin00younrich] (accessed on 10 September 2018).

Submitted: 24 June 2019. Revised: 19 September 2019. Accepted: 29 October 2019. Published on-line: 17 December 2019. 